УДК 376(73)(091):340.13

DOI: $10.24144 / 2524-0609.2021 .48 .39-43$

\author{
Bondar Tamara \\ Doctor of Pedagogical Sciences, Associate Professor \\ Department of Pedagogy for Pre-School, Primary Education and Educational Management \\ Mukachevo State University, Mukachevo, Ukraine \\ tamarabondar@yahoo.com \\ ORCID ID: http://orcid.org/0000-0001-9484-9336
}

\title{
HISTORICAL OVERVIEW OF U.S. INCLUSIVE EDUCATION FEDERAL LEGISLATION
}

\begin{abstract}
The relevance of the research problem tackling the inclusive education evolution in the United States is explained by the fact that it the USA has been a leader in developing a rights-based model of inclusive education. The research is conditioned by the current stage of national education that undergoes modernization, the steady course of Ukraine to create an inclusive school, and government's request to implement its initiatives. The purpose of this article is to present a reconsidered historical analysis of the inclusive education in the USA that represents an expansion of earlier research conducted by the author. Methods applied include historical and comparative research. The author's periodization that describes the phases in the inclusive education development in the USA is presented. This is based on the chronologically arranged U.S. federal legislation related to ensuring equal rights and opportunities. It is stated that some court decisions and federal legislation that incorporated court decisions clearly marked the phases in inclusive education development. These legislative milestones beginning each phase include the U.S. Supreme Court decision Brown v. Board of Education of Topeka (1954), the Education for All Handicapped Children Act (1975), the Education of the Handicapped Students Act Amendments (1986), No Child Left Behind Act (2001), and Every Student Succeeds Act (2015). Consequently, there are five phases in the inclusive education development and each phase reflects the general trend in the U.S. inclusive education. The initial phase is referred to as the active social movement for the right to education (1954-1974). In the second phase, children with disabilities were integrated into regular schools through mainstreaming (1975-1985). Then comes the so-called Regular Education Initiative phase or full inclusion (1986-2000), followed by the accountable inclusive education phase (2001-2014). Finally, the phase of the high-quality inclusive education started in 2015 and continues today.
\end{abstract}

Key words: least restrictive environment; federal legislation; students with disabilities; Regular Education Initiative; inclusive education.

Introduction. Education reforms have always meant changes. The USA started reforming schools in the 1950's after the U.S. Supreme Court decision Brown v. Board of Education of Topeka (1954). Since then, U.S. federal legislation has been shaping the general education environment so that it is accessible for all needy children. The U. S. federal policy has been focused on improving educational opportunities for all and impacting every student in America. Ukraine has been developing its inclusive education strategy since 2010. Although much has been gained, still more must be learned. Educators and lawmakers in Ukraine can learn from important conclusions made by the USA when developing its rights-based inclusive education model.

Literature Review. This research is largely based on the U.S. federal legislation analysis that shaped the U.S. school system and ensured that free, appropriate public education is accessible to all. Many federal laws were characterized in detail by R. Apling (the Individuals with Disabilities Act), L. Darling-Hammond, S. Fitzgerald, N. Reder, A. McColl (No Child Left Behind). To describe the trends within each phase in the inclusive education development the history of inclusive education presented by recognized American historians was analyzed (R. Osgood, P. Wolfe, P. Wright, M. Hossain). Works by P. Burke, J. Harvey, S. Kirk, P. Kleinhammer-Tramill, J. Peters, T. Fiore presented the overview of programs designed for special education personnel preparation and had a catalytic effect in the inclusion.

The purpose of this article is to present a reconsidered historical analysis of the inclusive education that represents an expansion of earlier research conducted by the author. This historical overview compares different approaches to identifying phases in the inclusive education development in the USA and traces the evolution of the federal legislation that had a huge impact on changing regular school environment for children with disabilities in the USA. To reach the goal several methods were used including historical research and comparative research. Historical research was used to analyze and interpret the historical material in order to gain the understanding of the present. It heled to identify phases and outline changes withing each phase of the inclusive education development. Comparative analysis enhanced the understanding of differences between each phase in the U.S. inclusion as well as to consider Ukraine's legislation when it was placed at the background of the U.S. legislation. It helped to evaluate the scope and significance of U.S. federal support based on its contribution to the inclusive education development. It also helps to predict challenges which our country can be faced with.

Results and discussion.

In 2014, research findings on phases in the inclusive education development in the USA presented a historical overview of fundamental federal laws that encouraged inclusive education practices in the USA. The five developmental phases at that point were thought to have been clearly identified and reflected both the efforts of advocacy groups, parents, inspired educators, and federal legislation shaping inclusive education [1]. Inclusive practices rooted in special education that started developing in the $50 \mathrm{~s}$ and $60 \mathrm{~s}$ of the $20^{\text {th }}$ century featured each phase and their impact on inclusion of children with disabilities. The author claimed that the initial phase started in the $50 \mathrm{~s}$ of the $20^{\text {th }}$ century marked by initiating several federal programs. These included the Education of the Mentally Retarded Children Act (P.L. 85-926) in 1958 and the Training of Professional Personnel Act (P.L. 86-158) of 1959. However, when analyzing the historical background deeper, it was concluded that there was another landmark case that caused the outpour of federal legislation, that in their turn caused the drastic changes in regular school environment in the USA. That was the U.S. Supreme Court decision Brown v. Board of Education of Topeka 
of 1954. It read that it is doubtful that any child may reasonably be expected to succeed in life if he is denied the opportunity of an education [4]. Considered a cornerstone case, Brown v. Board of Education made the USA first country in the world that developed the rights-based inclusive education model because of the powerful civil rights movement. It also ushered a new era for children with disabilities questioning the fairness of separate-but-equal education.

As the country still lacked the professionals who could support children with disabilities, there were some programs targeted at training personnel. In the 1960's Public Law 87-276 was issued including provisions for preparing teachers for children who were deaf. In 1963, Public Law 88-164 was signed into action, expanding the scope of training to prepare personnel for children with visual impairment, deafness and hearing impairment, mental retardation, speech impairment, serious emotional disturbance, and physical and health impairments [3].

Since exclusion practices were widely questioned in the courts, the Congress passed the Elementary and Secondary Education Act PL 89-10 (ESEA) in 1965, the first law that targeted the excluded groups. Following this in 1966, Title VI of this law established the Bureau of Education for the Handicapped (BEH) within the Office of Education, U.S. Department of Health, Education, and Welfare that provided research and appropriated funds for state and local education agencies that serve children with disabilities in regular elementary and secondary [6].

The second phase referred to as the integration though mainstreaming phase was ushered by the Education for All Handicapped Children Act P.L. 94142 (EAHCA) of 1975. Over the years it has been a landmark legislation that boosted the integration effort. Public schools were required to evaluate children with disabilities and develop an educational plan that would emulate as closely as possible the educational experience of non-disabled students. Parents' involvement in the plan development was mandatory. P.L. 94-142 contained guiding principles that outlined the requirements for least restrictive environment, that U.S. judicial term for inclusive education. This law also guarantees FAPE or free appropriate public education including preschool, elementary, or secondary school education in the State involved. Separate schooling was allowed only when the nature or severity of the disability did not allow the child to stay in the inclusive setting and instructional goals couldn't be achieved in the regular classroom. Finally, the law contains a due process clause that guarantees an impartial hearing to resolve conflicts between the parents of disabled children to the school system.

Initially, students with disabilities were mainstreamed into general education settings to integrate students with mild disabilities. However, being in a regular school that practiced integration, students with disabilities were separated, placed in special education classes, usually located in the same school and taught by special education professionals. Social integration with their non-disabled peers was practiced in art, PE, music classes or lunch and recess time. In short, mainstreaming was part of a two-system educational environment where special education and general education were separate [7, c. 4]. It should be noted that mainstreaming lacked collaboration of students with disabilities with their non-disabled peers. Until 1986 school personnel were not concerned about isolating students with disabilities. This period is characterized by the lack of initiative on the part of the general school teachers and presence of students with disabilities in the same school environment, however, separated, caused stress and still brought more parents to courts.

Phase 3 was ushered by the Regular Education Initiative phase advanced by the federal government and voiced by Madeleine C. Wills, Assistant Secretary for the Office of Special Education and Rehabilitative Services, U.S. Department of Education. The Regular Education Initiative was far from being that simplistic in nature as it called for cardinal revision of instructional programs for low-performing students. On the one hand, Madeleine C. Wills literally banned the separation practices calling for general education teachers to be responsible for students with learning difficulties. Her speech banned pulling out low-performing students for so-called remedial services in special settings. Thus, poor performance was equated with a disability. More intensive instruction could have assisted those students to become better learners. Instead, pulling out practices stigmatized students with learning difficulties and lowered academic expectations. On the other hand, according to the Assistant Secretary, the main flaw of the educational system was so-called "categorical approach" which left behind large numbers of students without additional support. That meant that millions of students were not eligible for additional support because they did not fall under the category of disability. That resulted in millions of students who could have become more successful academically if they had received more intense training [13]. This initiative called for coordinated services on behalf of professional personnel in a regular school setting.

Besides drastic changes in regular school environment, there were important changes related to young age children. The Education of the Handicapped Students Act Amendments of 1986 (P.L. 99-457) mandated services for children with disabilities in the 3-5 year age range and provided incentives for services to infants and toddlers with disabilities. Preparation of Personnel to Provide Early Intervention Services to Infants and Toddlers with Handicaps became a standalone absolute priority in FY 1989 [14]. This period also featured Americans with Disabilities Act (ADA) P.L.101-336 of 1990, Individual with Disabilities Education Act of 1990 P.L. 101-467, and its amendment in 1997 [2, c. 553-555].

Phase 4 called the accountable inclusive education phase was marked by the passage of the No Child Left Behind of 2001. This is the period of inclusion, that made wide state assessment for children with disabilities mandatory. The provisions of No Child Left Behind at the core, seek to 'drive broad gains in student achievement and to hold states and schools more accountable for student progress [10]. This law initiated challenges over assessment, Adequate Yearly Progress and an ambitious goal to staff every classroom with a highly qualified teacher by the 2005-2006 school year [8]. In particular, the changes brought by NCLB to special education were dramatic and unrealistic; the changes failed to recognize the wide-range of disabilities affecting over six million children in America [11]. Being the reauthorized Elementary and Secondary Education Act, NCLB was thought to decrease the achievement gap. As N. Shah noted, prior to the enactment of NCLB, states and districts still largely excluded students with disabilities from state testing programs. Schools cited various reasons for excluding students with disabilities from testing, including a desire to limit stress for those students, a lack of knowledge regarding test modifications and accommodations, and a goal to raise a school's overall scores [12]. To stop exclusion that was personally damaging to the students as well as to reform efforts, this law was enacted to ensure that all 
children have a fair, equal, and significant opportunity to obtain a high-quality education and reach, at a minimum, proficiency on challenging State academic achievement standards and state academic assessments. This law held states and districts accountable for the education of every American student.

Notwithstanding all great intentions, this law was heavily criticized by educators and lawmakers. The major concerns were placed on the curriculum that was viewed as narrow. In order to meet the benchmarks, teachers spent increased amounts of time to ensure students' with disabilities achievements in reading and math while neglecting other subjects. Another conflict rooted in the limited access to the general education curriculum. That meant that naturally students with disabilities did not possess the same skills as typical children, so their teaching was based on the special education program. Thus, being a high achiever in an adjusted general education curriculum differed from being a high achiever in general instruction. The worst of all was the situation that students with disabilities were considered the reasons for a school's failure to meet the State's AYP standards. And lastly, there was an issue of funding and the interventions services were highly costly and federal funding failed to cover these costs.

These and many other concerns were the reasons why the Every Student Succeeds Act (ESSA) was signed into law by President B. Obama in 2015. The main change is that ESSA as the latest reauthorization of the Elementary and Secondary Education Act (ESEA) of 1965, shifted key authority over funding, teacher evaluations, school improvement, and general transparency issues to states and districts [5]. In 2019, after four year enactment many educators and lawmakers were sure that it would effectively be the law of the land for years to come.

In 2020, under ESSA 46 states and territories were awarded initial PDG B-5 (Preschool Development Grant Birth through Five program) grants which provide competitive grants for states to improve early childhood education (ECE) coordination, quality, and access. After completing one year of planning, these states were eligible to apply for three-year renewal grants to support their implementation efforts.

There are already indicators of success that are reported constantly and include proficiency on assessments, student growth, high school graduation rates, progress of English learners and school quality or student success. States are granted the flexibility to identify and weight indicators within the requirements of ESSA to better evaluate school performance using both academic and non-academic components. As states worked to implement their plans, policymakers engaged key stakeholders to realize full implementation as well as tweak their accountability system to better align with the goals and priorities of the state [9]. The authors outline major achievements related to state plans and legislative action in all states. For instance, in March issue, Maryland, Kentucky, and New Mexico stated that their key issues are related to mapping out a new state accountability system, based on student growth and achievement. These changes are largely caused by the COVID 19 pandemic that pushed states to reevaluate their systems entirely.

Thus, the historic overview of the federal legislation allowed phasing the inclusive education development in the USA. Table 1 demonstrates reconsidered and expanded periodization compared to research findings of 2015.

Table 1.

The Inclusive Education Evolution in the USA

\begin{tabular}{|l|l|l|}
\hline \multicolumn{1}{|c|}{ Reconsidered evolution, 2021 } & Bondar, 2015 [1] & Hossain, 2012 [7] \\
\hline $\begin{array}{l}\text { Phase 1:1954-1974 } \\
\text { Brown v. Board of Education of Topeka } \\
\text { the active social movement for the right to } \\
\text { education phase }\end{array}$ & $\begin{array}{l}\text { Phase 1: } \\
\text { 1950's-1974 } \\
\text { the initial phase }\end{array}$ & $\begin{array}{l}\text { Phase 1 } \\
\text { 1900-1970's } \\
\text { the isolation phase. }\end{array}$ \\
\hline $\begin{array}{l}\text { Phase 2 } \\
\begin{array}{l}1975-1985 \\
\text { the integration though mainstreaming phase }\end{array}\end{array}$ & $\begin{array}{l}\text { Phase 2 } \\
1975-1986 \\
\text { the integration though } \\
\text { mainstreaming phase }\end{array}$ & $\begin{array}{l}\text { Phase 2 } \\
1975-2000 \\
\text { the integration phase }\end{array}$ \\
\hline $\begin{array}{l}\text { Phase 3: 1986-2000 } \\
\text { the Regular Education Initiative phase or } \\
\text { full inclusion initiative phase }\end{array}$ & $\begin{array}{l}\text { Phase 3 } \\
1986-1997 \\
\text { the Regular Education Initiative } \\
\text { phase }\end{array}$ & $\begin{array}{l}\text { Phase 3: 2001-2012 } \\
\text { the inclusion phase (no current } \\
\text { research to continue the } \\
\text { development is available) }\end{array}$ \\
\hline $\begin{array}{l}\text { Phase 4:2001-2014 } \\
\text { the accountable inclusive education phase }\end{array}$ & $\begin{array}{l}\text { Phase 4 } \\
1997-2001\end{array}$ & $\begin{array}{l}\text { Phase 5 } \\
2001-2015\end{array}$ \\
$\begin{array}{l}\text { Phase 5 } \\
\text { 2015 - present (2021) }\end{array}$ & \\
\hline
\end{tabular}

Conclusions. A comprehensive analysis of the inclusive education laws in the USA has been carried out to identify phases and trends that characterize these phases. It is recognized that the study of the inclusive education development requires an understanding of its concept as a complex system, which has defined goals, principles, functions, structure, and content. It is also a generalpedagogical, multi-tiered phenomenon that is influenced by a specific historical context, constantly impacted by the social, political, economic, and cultural issues that characterize the context of the U.S. education. The U.S. legislation does not define «inclusive education»; the term «least restrictive environment» is used instead. Because of the Regular Education Initiative (RtI) since
1986, inclusive education has been interpreted as the obligation to provide the highest quality educational support to every child in school classrooms; placement of students with disabilities in special classes or schools or other exclusion from regular education takes place only when these students need extremely intensive support.

The period between 1954 and the present was divided into 5 phases; each phase is characterized by its own trends and developments. U.S. federal legislation including the Education for All Handicapped Children Act (1975), the Education of the Handicapped Students Act Amendments (1986), No Child Left Behind Act (2001), and Every Student Succeeds Act (2015) were identified as landmarks. It is also stated that the USA 
seems to be the first country to develop a rights-based inclusive education since 1954. Further research may

include the analysis of approaches that U.S. states use currently to map out their accountability system.

\section{Список використаної літератури}

1. Бондар Т. І. Етапи розвитку інклюзивної освіти у США. Науковий вісник Ужсгородського наиіонального університету. Серія: Педагогіка. Соиіальна робота. 2015. Вип. 37. С. 16-19.

2. Бондар Т. І. Тенденції розвитку інклюзивної освіти у США та Канаді: дис. ... д-ра пед. наук: 13.00 .01 / Хмельницька гуманітарно-педагогічна академія МОН України, Хмельницький, 2019. 607 с.

3. Burke P.J. Personnel preparation: Historical perspective. Exceptional Children. 1976. № 43. P. 144-147.

4. Case of Brown v. Board of Education of Topeka, 347 U.S. 483. Decided May 17, 1954. URL: https://supreme.justia.com/cases/ federal/us/347/483/ (дата звернення: 14.04.2018).

5. ESSA Voices: The Every Student Succeeds Act, Four Years Later. URL: https://www.edweek.org/policy-politics/essa-voicesthe-every-student-succeeds-act-four-years-later/2019/12 (дата звернення: 14.04.2021).

6. Harvey J. Personnel preparation for the handicapped: Into the third decade. Unpublished. Washington, DC: U.S. Office of Education, Bureau of Education of the Handicapped 1980. 280

7. Hossain M. An Overview of Inclusive Education in the United States. K-12 Education: Concepts, Methodologies, Tools and Applications. 1st ed. IGI Global 2012. P. 1-25.

8. Kleinhammer-Tramill J., Fiore T. A. A History of Federal Support for Preparing Special Educators and Related Services Personnel to Serve Children and Youth with Disabilities. Teacher Education and Special Education. 2003. № 26(3). P. $217-229$.

9. McCann M., Erwin B., Freemire L. The Every Student Succeeds Act: 5 Years Later. (March 21, 2021). URL: https://ednote.ecs. org/the-every-student-succeeds-act-5-years-later/. (дата звернення: 12.04.2021).

10.Public Law. No Child Left Behind. 2001. URL: https://www.congress.gov/107/plaws/publ110/PLAW-107publ110.htm (дата звернення:: 14.06.2018).

11. Reder N.D. Accountability for Students with Disabilities, National Association of Special Education. 2007. URL: http://www. nasdse.org/Portals/0/Documents/1 ACCOUNTABILITY\%/-20FOR\%/o2OSTUDENTS\%/20WITH\%/ 20DISABILITIES. pdf (дата звернення: 12.04.2021)

12.Shah N. Including, Excluding Students with Disabilities Under NCLB. http://blogs.edweek.org/edweek/speced/2012/05/ including excluding students with.html?qs=NCLB+ special education (дата звернення: 12.04.2021).

13.The Regular Education Initiative: A Statement by the Teacher Education Division, Council for Exceptional Children October 1986. URL: https://journals.sagepub.com/doi/abs/10.1177/002221948702000508?journalCode=ldxa (дата звернення: 12.04.2021).

14.U.S. Department of Education, Office of Special Education and Rehabilitation Services, Training personnel for the education of the handicapped, application notice, 53 FR 13657 (November 10, 1988). (дата звернення: 11.11.2020).

\section{References}

1. Bondar, T. I. (2015). Etapy rozvytku inkliusyvnoi osvity u SSHA [Phases in the U.S. inclusive education development]. Scientific Herald of Uzhhorod University. Series: Pedagogy. Social Work, 37, 16-19. [in Ukrainian].

2. Bondar, T.I. (2019). Tendentsiyi rozvytku inklyuzyvnoyi osvity u SSHA ta Kanadi [Trends in the Development of Inclusive Education in the USA and Canada] [Unpublished Doctoral dissertation]. Bohdan Khmelnytskyi Cherkasy National University. [in Ukrainian].

3. Burke, P.J. (1976). Personnel preparation: Historical perspective. Exceptional Children, 43, 144-147.

4. Case of Brown v. Board of Education of Topeka, 347 U.S. 483. Decided May 17, 1954. https://supreme.justia.com/cases/ federal/us/347/483/

5. ESSA Voices: The Every Student Succeeds Act, Four Years Later. https://www.edweek.org/policy-politics/essa-voices-theevery-student-succeeds-act-four-years-later/2019/12

6. Harvey, J. (1980). Personnel preparation for the handicapped: Into the third decade. Unpublished. U.S. Office of Education, Bureau of Education of the Handicapped

7. Hossain, M. (2012). An Overview of Inclusive Education in the United States. K-12 Education: Concepts, Methodologies, Tools and Applications. IGI Global.

8. Kleinhammer-Tramill, J., \& Fiore, T. A. (2003). A History of Federal Support for Preparing Special Educators and Related Services Personnel to Serve Children and Youth with Disabilities. Teacher Education and Special Education, 26 (3), $217-229$.

9. McCann, M., Erwin, B., \& Freemire, L. (March 21, 2021). The Every Student Succeeds Act: 5 Years Later. https://ednote.ecs. org/the-every-student-succeeds-act-5-years-later/.

10.Public Law (2001). No Child Left Behind. https://www.congress.gov/107/plaws/publ110/PLAW-107publ110.htm

11.Reder, N.D. (2007). Accountability for Students with Disabilities, National Association of Special Education. http://www. nasdse.org/Portals/0/Documents/1 ACCOUNTABILITY\%/-20FOR\%/o2OSTUDENTS\%/ 20WITH\%/ 20DISABILITIES.pdf

12.Shah, N. Including, Excluding Students with Disabilities Under NCLB. http://blogs.edweek.org/edweek/speced/2012/05/ including excluding students with.html?qs=NCLB+ special education

13. The Regular Education Initiative: A Statement by the Teacher Education Division, Council for Exceptional Children October 1986. https://journals.sagepub.com/doi/abs/10.1177/002221948702000508?journalCode=ldxa (last accessed April, 2021).

14.U.S. Department of Education, Office of Special Education and Rehabilitation Services, Training personnel for the education of the handicapped, application notice, 53 FR 13657 (November 10, 1988).

Стаття надійшла до редакції 15.04.2021 р. Стаття прийнята до друку 20.04.2021 р.

\section{Бондар Тамара Іванівна}

доктор педагогічних наук, доцент

завідувач кафедри педагогіки дошкільної, початкової освіти та освітнього менеджменту

Мукачівський державний університет, м. Мукачево, Україна

\section{ІСТОРИЧНИЙ АНАЛІЗ РОЗВИТКУ ІНКЛЮЗИВНОЇ ОСВІТИ У США: ФЕДЕРАЛЬНЕ ЗАКОНОДАВСТВО}

Анотація. Актуальність проблеми дослідження розвитку інклюзивної освіти у США обумовлена сучасним етапом модернізації вітчизняної освіти, неухильним курсом України на створення інклюзивної школи, реалізації ініціатив уряду з розв'язання цієї проблеми. Мета дослідження полягає у перегляді історичного 
аналізу інклюзивної освіти США, що уточнює результати попередніх досліджень автора. Цей історичний огляд порівнює різні підходи до визначення етапів розвитку інклюзивної освіти в США та простежує еволюцію федерального законодавства, що формує загальноосвітнє середовище США. Для розв'язання завдання дослідження застосовано історико-ретроспективний метод для послідовного розкриття генези розвитку інклюзивної освіти, систематизації історіографії порушеної проблеми, уточнення періодизації розвитку інклюзивної освіти окресленого періоду; історико-компаративний - для порівняльного аналізу становлення й опису тенденцій розвитку інклюзивної освіти. Представлено уточнені етапи розвитку інклюзивної освіти США у форматі авторської періодизації, в основу яких покладено хронологію розвитку законодавчої бази країни: етап активного соціально-правового руху за рівні права на освіту (1954-1974 pр.), етап інтеграції дітей 3 інвалідністю до ЗМШ через мейнстримінг (1975-1985 рр.), «Ініціатива загальної освіти» (повна інклюзія) (1986-2000 рр.); етап відповідальної інклюзивної освіти (2001-2014 рр.), етап якісної інклюзивної освіти (2015-дотепер). Констатовано, що інклюзивна у США розвивається у правовій парадигмі з 1954 р. під впливом активного соціально-правового руху за рівні права на освіту.

Ключові слова: найменш обмежувальне середовище; федеральне законодавство; учні з інвалідністю; ініціатива загальної освіти; інклюзивна освіта. 